\title{
PEMETAAN DAERAH PENANGKAPAN IKAN CAKALANG (Katsuwonus pelamis) DENGAN TEKNIS SISTEM INFORMASI GEOGRAFIS DI PERAIRAN KABUPATEN TOLITOLI PROVINSI SULAWESI TENGAH
}

\section{MAPPING OF SKIPJACK TUNA (Katsuwonus pelamis) FISHING GROUND USING GEOGRAPHIC INFORMATION SYSTEM TECHNICALLY AT TOLITOLI COSTAL WATER CENTRAL OF CELEBES}

\author{
Fadhil Moh Fauzan ${ }^{1^{*}}$, Mukti Zainuddin ${ }^{1}$, dan Andi Assir Marimba ${ }^{1}$ \\ ${ }^{1}$ Program Studi Pemanfaatan Sumberdaya Perikanan, FIKP, Universitas Hasanuddin
}

Diterima: 03 Januari 2019; Disetujui: 15 Februari 2019

\begin{abstract}
ABSTRAK
Penelitian ini bertujuan untuk mengetahui hubungan antara tangkapan ikan cakalang (Katsuwonus pelamis) dengan parameter oseanografi (suhu permukaan laut, kedalaman, klorofil-a, kecepatan arus dan salinitas), memetakan daerah tangkapan ikan cakalang (Katsuwonus pelamis) dengan parameter oseanografi dan memprediksi daerah penangkapan potensial ikan cakalang di perairan Tolitoli menggunakan sistem informasi geografis secara teknis. Penelitian ini dilakukan pada bulan Maret hingga Juni 2018 di Kabupaten Tolitoli. Metode pengumpulan data adalah metode survei pole and line dan purse seine dengan mengumpulkan 50 lokasi titik tangkapan. Data yang dikumpulkan adalah posisi penangkapan, hasil tangkapan, dan data oseanografi lapangan. Analisis data menggunakan regresi linier berganda non parametrik (Cobb douglas). Prediksi potensi area penangkapan ikan cakalang menggunakan perangkat lunak ArcGis. Distribusi tuna cakalang di perairan Kabupaten Tolitoli dengan kisaran suhu permukaan laut 29,5$31,1^{\circ} \mathrm{C}$, kedalaman $14,20-5513 \mathrm{mdpl}$, konsentrasi klorofil-a $0,10-0,23 \mathrm{mg} / \mathrm{m}^{3}$, kecepatan arus 0,12 - 0,72 $\mathrm{m} / \mathrm{s}$ dan salinitas 32,74 - 33,64 ppt. Parameter klorofil-a, kecepatan arus, salinitas memiliki hubungan nyata dengan tangkapan ikan cakalang. Prediksi potensial dan temporal dari area potensial percakapan cakalang selama masa studi di Kabupaten Tolitoli umumnya terletak di antara Selat Makassar dan Laut Sulawesi. Titik koordinat antara $0^{\circ} 57^{\prime} 53,43$ "LU hingga $2^{\circ} 1$ '38.411" LU dan $119^{\circ} 24^{\prime} 58.034$ "BT hingga $121^{\circ} 16^{\prime} 4.157^{\prime \prime}$ BT dengan total area ZPPI $16.461 .75 \mathrm{~km}^{2}$.
\end{abstract}

Kata Kunci: Ikan cakalang, daerah penangkapan, Klorofil-a, kecepatan arus, salinitas

\begin{abstract}
This research has purpose for knowing the relationship between the catches of skipjack tuna (Katsuwonus pelamis) with oceanographic parameters (sea surface temperature, depth, chlorophyll-a, velocity of current and salinity), mappping the catching area of skipjack (Katsuwonus pelamis) with oceanographic parameters and predicting potential fishing areas of skipjack fish at Tolitoli costal water using geographic information system technically. This research was during from March to June 2018 in Tolitoli District. The data collection method is the pole and line and purse seine survey method by collecting 50 coordinates of the catch point location. The data collected were fishing positions, catches, and field oceanographic data. Data analysis using
\end{abstract}


non parametric multiple linear regression (Cobb douglas). Prediction of potential fishing areas of skipjack tuna used ArcGis software. Distribution of skipjack tuna in Tolitoli district waters with a range of sea surface temperature of $29.5-31.1{ }^{\circ} \mathrm{C}$, depth of $14.20-5513$ masl, chlorophyll-a concentration of $0.10-0.23 \mathrm{mg} / \mathrm{m}^{3}$, velocity of current of $0.12-0.72 \mathrm{~m} / \mathrm{s}$ and salinity $32.74-33.64 \mathrm{ppt}$. The parameters of chlorophyll-a, velocity of current, salinity have a real relationship with the catch of skipjack. Potential and temporal predictions of the potential area of conversations of skipjack tuna during the study period in Tolitoli district generally located between Makassar strait and the Sulawesi sea. the coordinate points of beetween $0^{\circ} 57^{\prime} 53,43^{\prime \prime} \mathrm{LU}$ to $2^{\circ} 11^{\prime} 38,411^{\prime \prime} \mathrm{LU}$ and $119^{\circ} 24^{\prime} 58,034^{\prime \prime B T}$ to $121^{\circ} 16^{\prime} 4,157^{\prime \prime}$ BT with the total area of ZPPI being $16.461,75 \mathrm{~km}^{2}$.

Keywords: Skipjack tuna, Fishing Ground, chlorophyll-a, velocity of current, salinity

\begin{tabular}{ll}
\hline Contact person & : Fadhil Moh Fauzan \\
E-Mail & $:$ fadhilfauzan007@gmail.com
\end{tabular}

\section{PENDAHULUAN}

Kabupaten Tolitoli merupakan salah satu Kabupaten di Provinsi Sulawesi Tengah. Luas wilayah Kabupaten Tolitoli 4.079,77 km2 daratan dan 300.859,22 Ha wilayah lautan dengan panjang garis pantai 453,98 $\mathrm{km}^{2}$ potensi perikanan tangkap sebesar kurang lebih $15.116,93$ ton per tahun. Salah satu komuditas perikanan unggulan dari Kabupaten Tolitoli ialah ikan Cakalang (Yuliani dkk., 2013).

Total produksi ikan cakalang di Kabupaten Tolitoli selama tahun 2017 yaitu 16.436 ton. Produksi tangkapan tertinggi ikan Cakalang yaitu pada triwulan 2 dengan total produksi 5235 ton, sedangkan produksi tangkapan terendah yaitu pada triwulan 4 dengan total produksi yaitu 2938 ton (DKP Kab. Tolitoli, 2018).

Pada umumnya, aktivitas penangkapan ikan cakalang di perairan Tolitoli menggunakan purse seine dan pole and line yang banyak terdapat di Pelabuhan Dede Kabupaten Tolitoli. Dalam pengoperasian penangkapan salah satu kendala dalam menangkap cakalang adalah lemahnya informasi tentang fishing ground baik secara spasial maupun temporal. Kondisi iklim yang berubah-ubah semakin menyulitkan dalam menentukan fishing ground ikan cakalang, sehingga kegiatan penangkapan kurang efektif, boros bahan bakar dan boros waktu namun hasilnya kurang optimal. Hal ini akan efektif dan efisien apabila fishing ground target tangkapan dapat diduga terlebih dahulu.

Teknologi satelit penginderaan jauh dapat digunakan untuk menemukan karakteristik oseanografi termasuk daerah penangkapan ikan tuna dan cakalang. Penggunaan citra suhu permukaan laut (SPL) dan citra konsetrasi klorofil-a telah dibuktikan mampu mendeteksi daerah penangkapan ikan tuna yang produktif (Zainuddin dkk., 2004; 2006). 
Penelitian ini dilakukan untuk memetakan daerah panangkapan ikan, khususnya ikan cakalang di perairan Kabupaten Tolitoli dengan memetakan daerah penangkapan ikan cakalang melalui pengamatan berbagai parameter oseanografi secara langsung serta dipadukan dengan penggunaan teknologi untuk memperoleh data dan informasi tentang karakteristik oseanografi di perairan tersebut. Serta

memprediksi

daerah

penangkapan potensial ikan cakalang.

\section{DATA DAN METODE}

Penelitian ini dilaksanakan pada bulan Maret sampai Juni 2018 di perairan Tolitoli, Sulawesi Tengah dengan fishing base di Pelabuhan Dede Kelurahan Sidoarjo, Kabupaten Tolitoli.

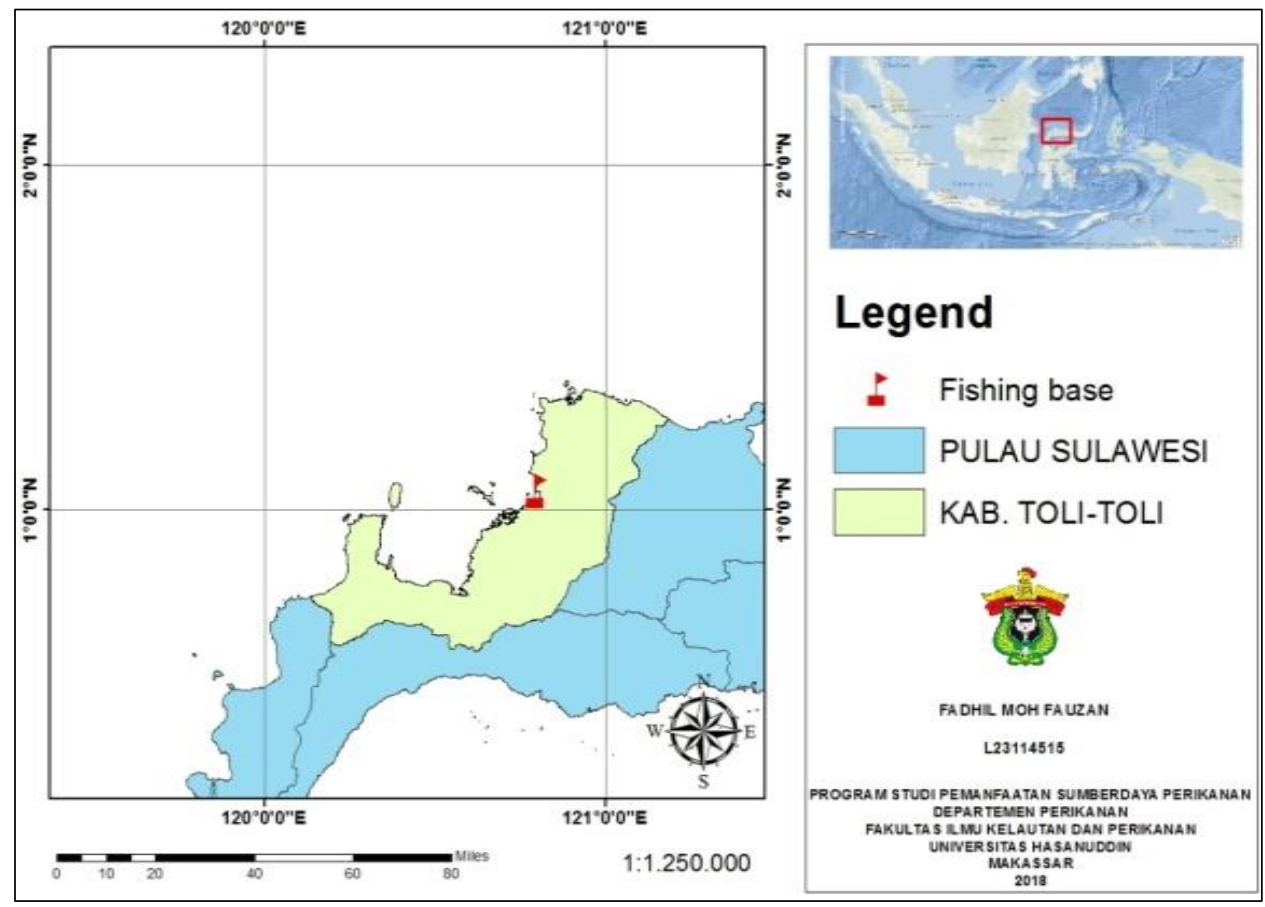

Gambar 1. Lokasi Penelitian

Tabel 1. Bahan dan Alat yang digunakan

\begin{tabular}{|c|c|c|}
\hline No. & Bahan dan Alat & Kegunaan \\
\hline 1. & $\begin{array}{l}\text { Unit penangkapan pole and line dan } \\
\text { purse seine }\end{array}$ & Penangkapan ikan cakalang \\
\hline 2. & Global positioningsystem (GPS) & $\begin{array}{l}\text { Menetukan titik koordinat fishing base dan } \\
\text { fishing ground }\end{array}$ \\
\hline 3. & Kamera & Dokumentasi selama kegiatan penelitian berlangsung \\
\hline 4. & Alat tulis menulis & Mencatat data yang diperoleh \\
\hline 5. & Termometer digital & Mengukur suhu permukaan laut \\
\hline 6. & $\begin{array}{l}\text { Komputer dan software (ArcGIS10.3, } \\
\text { SeaDas,Origin 8.5.1 dan SPSS) }\end{array}$ & $\begin{array}{l}\text { Sarana pengolahan data dan virtualisasi sebaran parameter } \\
\text { oseanografi dan hasil tangkapan }\end{array}$ \\
\hline 7. & Layaran arus & Mengukur kec. Arus \\
\hline 8. & Refarakto meter & Mengukur salinitas \\
\hline
\end{tabular}




\section{Metode Pengambilan Data}

Dalam penelitian ini, pengambilan dan pencatatan data lapangan yang dilakukan selama mengikuti operasi penangkapan ikan, meliputi ; posisi penangkapan ikan, hasil tangkapan ikan cakalang (ekor), suhu permukaan laut (SPL), kedalaman, klorofil-a, kecepatan arus, dan salinitas secara in-situ dan ex-situ (citra satelit).

\section{Analisis Data}

Untuk mengetahui hubungan parameter oseanografi dan hasil tangkapan juga digunakan analisis cobb douglas. Formulasi dari analisis tersebut sebagai berikut (Ramadhani. Y, 2011) :

\section{$\log \hat{Y}=a+b_{1} \log x_{1}+b_{2} \log x_{2}+b_{3} \log x_{3}+b_{4} \log x_{4}+b_{5} \log x_{5}$}

Dimana :

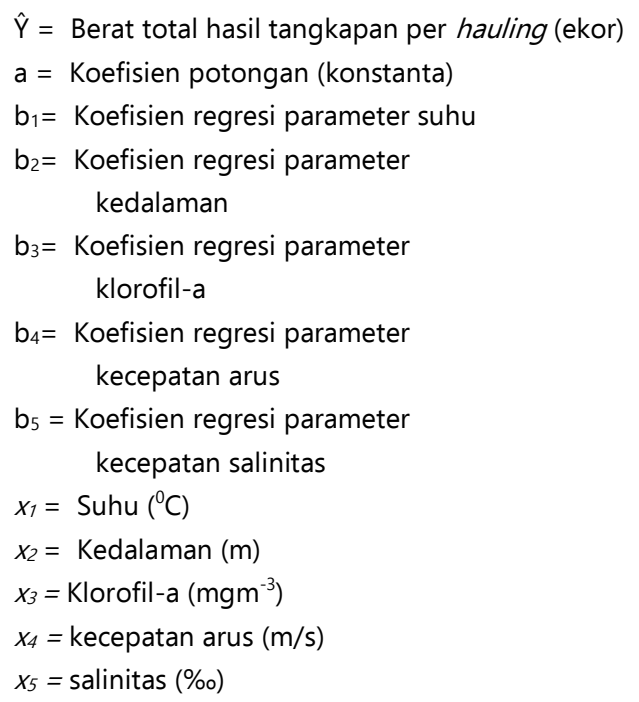

Analisis regresi yang baik harus memenuhi beberapa syarat antara lain, uji normalitas, uji multikolinearitas, analisis varians $(F)$, analisis koefisien regresi (uji t).

Pemetaan dan prediksi daerah potensial ikan cakalang dilakukan analisis sistem informasi geografis (SIG) dengan menggunakan ArcGIS 10.3.

\section{HASIL DAN PEMBAHASAN}

\section{Keadaan Umum Lokasi}

Wilayah perairan Kabupaten Tolitoli berdasarkan letak geografisnya berada di Selat Makassar dan Laut Sulawesi. Wilayah ini adalah salah satu celah pelayaran laut international yang selalu dilewati oleh kapal asing. Di samping itu, berdasarkan pengamatan yang telah dilakukan, wilayah ini juga merupakan jalur migrasi dari ikan tuna baik dari utara ke selatan maupun sebaliknya (Yuliani dkk., 2013). 
Perairan Tolitoli yang berada pada daerah pertemuan Laut Sulawesi dan Selat Makassar memiliki karakteristik perairan oseanik yang diduga mendapat pengaruh besar dari fenomena Arus Lintas Indonesia (ARLINDO). Pengaruh Arlindo diperkirakan turut membantu dalam distribusi biota laut di kawasan Indo-Pasifik dan sekaligus memicu keanekaragaman biota yang tinggi akibat peningkatan kesuburan dan kualitas perairan yang berkesinambungan (Wirasatriya, 2011).

\section{Analisis Parameter Oseonografi Terhadap Hasil Tangkapan}

a. Uji normalitas

Berdasarkan hasil uji normalitas residu terhadap 50 data primer yang telah dikumpulkan dapat diketahui bahwa residu hasil tangkapan mengikuti distribusi normal. Hasil dari uji normalitas di dapatkan nilai signifikan adalah 0,820 dengan demikian dapat diketahui bahwa nilai residu hasil tangkapan terdistribusi normal dengan mengikuti asumsi bahwa $p$-value lebih besar dari 0,05 ( $p$-value > $0,05)$.

Untuk mengetahui hubungan parameter oseonografi dengan hasil tangkapan pada penelitian ini dilakukan analisis regresi linear berganda terhadap variabel bebas dan variabel tak bebas. Berdasarkan hasil pengukuran parameter suhu (X1), kedalaman(X2), klorofil-a (X3), kecepatan arus (X4), dan salinitas (X5) sebagai variabel bebas (independent), sedangkan hasil tangkapan ikan cakalang (Y) sebagai varibel tak bebas (dependent). Parameter suhu,kedalaman, klorofil-a, kecepatan arus, dan salinitas diduga memilki hubungan dan pengaruh terhadap hasil tangkapan ikan cakalang.

Berdasarkan hasil regresi, diperoleh nilai korelasi regresi berganda antara variabel parameter oseonografi (suhu, klorofil, kedalaman, kecepatan arus dan salinitas) dengan hasil tangkapan. Untuk korelasi tersebut dapat dilihatpada tabel 2 berikut ini.

Tabel 2. Nilai korelasi regresi berganda antara variabel hasil tangkapan cakalang (Katsuwonus pelamis) dengan variabel parameter oseonografi.

\section{Model Summary ${ }^{b}$}

\begin{tabular}{lcccc}
\hline \multicolumn{1}{c}{ Model } & $\mathrm{R}$ & $\mathrm{R}^{2}$ & Adjusted R Square & Std. Error of the Estimate \\
\hline 1 & $.685^{\mathrm{a}}$ & .469 & .350 & 377.35378 \\
\hline & & & \\
\hline \multicolumn{2}{l}{ a. Predictors: (Constant), salinitas, suhu, kedalaman, kec. arus, klorofil } \\
\hline
\end{tabular}


Dapat dilihat pada Tabel 5 uji multikolineritas nilai VIF kelima variabel bebas kurang dari 10 dan nilai tolerance lebih dari 0,01 maka dapat disimpulkan dengan bahwa tidak terdapat masalah multikolinearitas dalam model regresi. Model regresi linear berganda koefisien determinasi $R$ Square $\left(R^{2}\right)$ adalah 0,46 artinya $46 \%$ yang terjadi terhadap hasil tangkapan disebabkan variabel suhu, kedalaman, klorofil-a, kecepatan arus, salinitas, dan sisanya $54 \%$ dipengaruhi oleh faktor lain. Faktor lain yang diduga berpengaruh adalah penggunaan umpan pada operasi penangkapan, dimana kecenderungan

cakalang untuk memakan jenis umpan yang dipakai oleh nelayan pada umumnya tidak menentu, sehingga nelayan pada saat operasi penangkapan selalu membawa beberapa jenis

umpan yang berbeda yaitu umpan hidup (teri, layang dan tembang). Pengaruh yang diberikan oleh umpan ini sangat besar sesuai dengan pendapat Sadhori (1985), bahwa umpan merupakan salah satu faktor yang sangat besar pengaruhnya terhadap keberhasilan dalam upaya penangkapan baik masalah jenis umpan, sifat umpan maupun cara ikan memakan umpan. Selain itu hasil penelitian Cayre et al (1993) dalam Watimury (1998), bahwa dalam suatu kelompok ikan cakalang dan madidihang (yellowfin tuna) tidak selalu dapat mengkonsumsi mangsa yang sama tetapi bagaimanapun dapat memiliki preperensi untuk ikan yang sama selama mereka mampu menangkapnya.

b. uji $f$

Hasil uji F dapat dilihat kelima faktor oseanografi secara bersama-sama berpengaruh nyata terhadap hasil yang tangkapan ikan cakalang. Hal ini dapat lihat pada nilai signifikansi pada Tabel 3 adalah $0.004<0.05$, dan Fhitung lebih besar dari Ftabel (4.106>2.58), ini menunjukan bahwa parameter oseanografi diantaranya suhu permukaan laut , kedalaman, klorofil-a, kecepatan arus, dan salinitas serta secara bersama-sama berhubungan nyata terhadap hasil tangkapan ikan cakalang di perairan Tolitoli.

c. Uji t

Hasil uji $t$ menunjukan bahwa secara individu pada model ketiga hanya faktor suhu permukaan laut (SPL), kedalaman dan kecepatan arus yang mempengaruhi hasil tangkapan secara signifikan. Dengan nilai probabilitas dari masing-masing parameter oseaografi tersebut adalah klorofil (X3) probabilitas (Sig) $0.049<0.05$, kec. Arus(X4) probabilitas (Sig) $0.008<0.05$, salinitas (X5) probabilitas (Sig) $0.011<0.05($ Tabel 4), 
sehingga dapat disimpulkan bahwa perubahan klorofil (X3), kecepatan arus (X4) dan salinitas (X5) berpengaruh nyata terhadap hasil tangkapan ikan cakalang (Y). Sedangkan untuk variabel, suhu (X1), dan kedalaman (X2),

Tabel 3. Hasil uji $\mathrm{f}$

ANOVA $^{\text {b }}$

\begin{tabular}{|ll|r|r|r|r|r|}
\hline Model & & Sum of Squares & Df & Mean Square & F & \multicolumn{1}{|c|}{ Sig. } \\
\hline 1 & Regression & 2695298.618 & 5 & 539059.724 & 4.106 & $.004^{\mathrm{a}}$ \\
& Residual & 5776002.362 & 44 & 131272.781 & & \\
& Total & 8471300.980 & 49 & & & \\
\hline
\end{tabular}

a. Predictors: (Constant), salinitas, suhu, kedalaman, kec. arus, klorofil

b. Dependent Variable: hasil tangkapan (ekor)

Tabel 4. Hasil uji t

\begin{tabular}{|c|c|c|c|c|c|c|}
\hline \multirow{2}{*}{\multicolumn{2}{|c|}{ Model }} & \multicolumn{2}{|c|}{ Unstandardized Coefficients } & \multirow{2}{*}{$\begin{array}{c}\begin{array}{c}\text { Standardized } \\
\text { Coefficients }\end{array} \\
\text { Beta }\end{array}$} & \multirow[b]{2}{*}{$\mathrm{T}$} & \multirow[b]{2}{*}{ Sig. } \\
\hline & & B & Std. Error & & & \\
\hline \multirow[t]{6}{*}{1} & (Constant) & -22590.750 & 10196.447 & & -2.216 & .032 \\
\hline & Suhu & -49.800 & 137.999 & -.067 & -.361 & .720 \\
\hline & Kedalaman & -.057 & .072 & -.104 & -.786 & .436 \\
\hline & Klorofil-a & -7256.616 & 3612.335 & -.370 & -2.009 & .049 \\
\hline & kec. Arus & -1005.330 & 363.139 & -.382 & -2.768 & .008 \\
\hline & Salinitas & 782.243 & 294.914 & .345 & 2.652 & .011 \\
\hline
\end{tabular}

a. Dependent Variable: hasil tangkapan (ekor)

Tabel 4. Uji Multikolinearitas

Coefficients $^{a}$

\begin{tabular}{|c|c|c|c|c|c|c|c|c|}
\hline \multirow{2}{*}{\multicolumn{2}{|c|}{ Model }} & \multicolumn{2}{|c|}{ Unstandardized Coefficients } & \multirow{2}{*}{$\begin{array}{c}\text { Standardized } \\
\text { Coefficients } \\
\text { Beta }\end{array}$} & \multirow[b]{2}{*}{$\mathrm{t}$} & \multirow[b]{2}{*}{ Sig. } & \multicolumn{2}{|c|}{ Collinearity Statistics } \\
\hline & & B & Std. Error & & & & Tolerance & VIF \\
\hline \multirow[t]{6}{*}{1} & (Constant) & -22590.750 & 10196.447 & & -2.216 & .032 & & \\
\hline & Suhu & -49.800 & 137.999 & -.067 & -.361 & .720 & .448 & 2.231 \\
\hline & kedalaman & -.057 & .072 & -.104 & -.786 & .436 & .887 & 1.128 \\
\hline & Klorofil & -7256.616 & 3612.335 & -.370 & -2.009 & .049 & .457 & 2.188 \\
\hline & kec. arus & -1005.330 & 363.139 & -.382 & -2.768 & .008 & .813 & 1.231 \\
\hline & salinitas & 782.243 & 294.914 & .345 & 2.652 & .011 & .917 & 1.091 \\
\hline
\end{tabular}


a. Dependent Variable: hasil tangkapan (ekor)

Adapun persamaan regresi yang melibatkan variabel yang berhubungan saja (klorofil-a, kec. arus dan salinitas) atau dapat juga dilakukan estimasi dengan pendekatan metode stepwise, sehingga persamaan yang terbentuk adalah :

$Y=-24418.827-6968.194 x_{3}-930.364 x_{4}+793.886 x_{5}+e$

Nilai-nilai koefisien ini digunakan untuk mengetahui besarnya proporsi dari Klorofil-a $\left(X_{3}\right)$, kecepatan arus $\left(X_{4}\right)$ \& salinitas $\left(X_{5}\right)$ terhadap hasil tangkapan $(\mathrm{Y})$.

Berdasarkan persamaan regresi yang didapatkan, dapat diketahui bahwa:

1. Koefisien Klorofil-a $\left(X_{3}\right)$ yang bernilai negatif yakni $-6968,194$. Hal ini menunjukkan setiap kenaikan kandungan klorofil-a $1 \mathrm{mg} / \mathrm{m}^{3}$, maka hasil tangkapan juga berkurang sebesar -6968,194 ekor dengan asumsi bahwa parameter kecepatan arus dan salinitas tetap.

2. Koefisien kecepatan arus $\left(X_{4}\right)$ yang bernilai negatif yakni 930,364. Hal ini menunjukkan setiap kenaikan kecepatan arus $1 \mathrm{~m} / \mathrm{s}$, maka hasil tangkapan juga berkurang sebesar 930,364 ekor dengan asumsi bahwa parameter klorofil-a dan salinitas tetap.

3. Koefisien salinitas $\left(X_{5}\right)$ yang bernilai positif yakni 793,886. Hal ini menunjukkan setiap kenaikan salinitas 1 ppt, maka hasil tangkapan juga bertambah sebesar 793,886 ekor dengan asumsi bahwa parameter klorofil-a dankecepatan arus tetap.

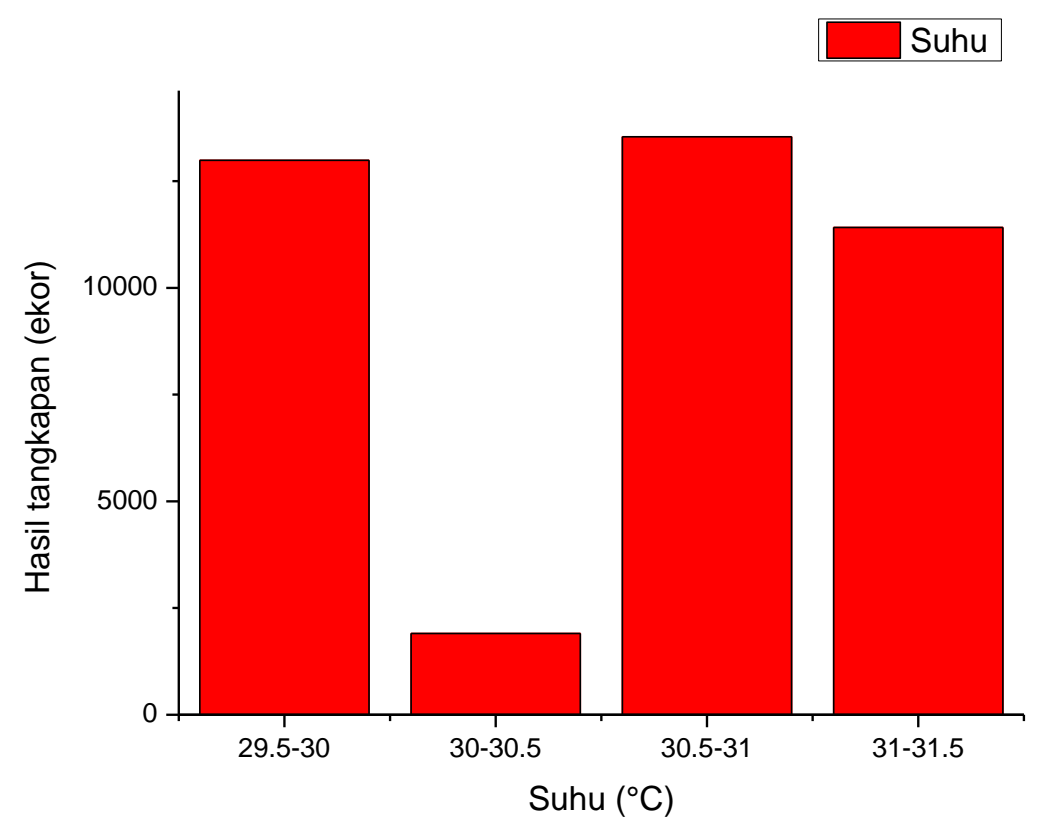

Gambar 2. Grafik hasil tangkapan ikan cakalang bedasarkan SPL 
Pada grafik di atas, dapat diketahui diperoleh nilai propabilitas (sig) sebesar bahwa suhu permukaan laut optimum ikan 0,720>0,05, sehingga dapat diasumsikan cakalang (Katsuwonus pelamis) antara 30,5- bahwa perubahan variabel suhu permukaan $31,0{ }^{\circ} \mathrm{C}$ memiliki jumlah hasil tangkapan laut (X1) tidak berpengaruh nyata terhadap tertinggi yaitu 13538 ekor.Berdasarkan hasil hasil tangkapan ikan cakalang.

uji-t untuk variabel suhu permukaan laut (X1)

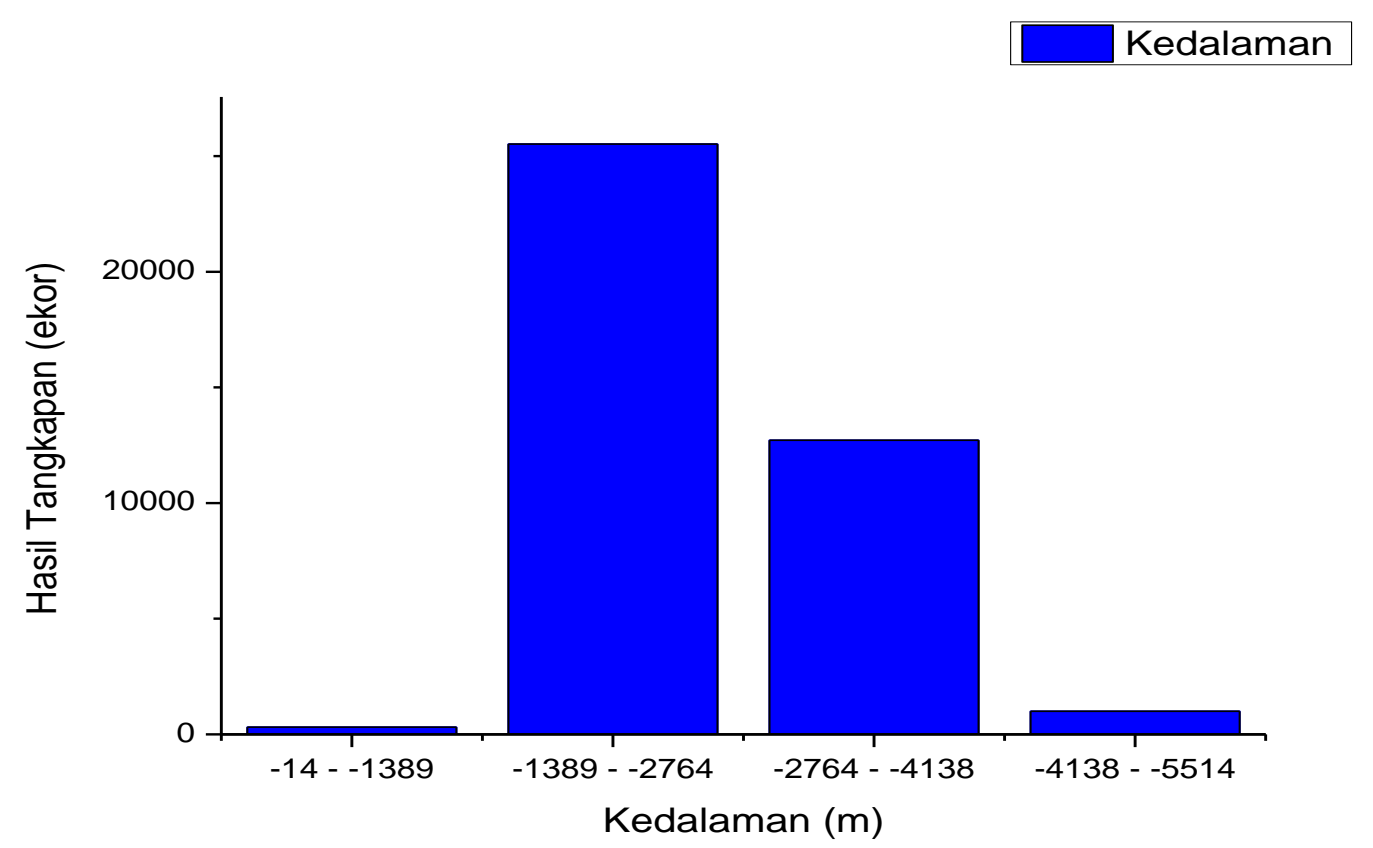

Gambar 3. Grafik hasil tangkapan ikan cakalang berdasarkan kedalaman

variabel kedalaman (X2) diperoleh nilai

Pada grafik di atas, dapat diketahui bahwa kedalaman perairan antara 1389 - 2784 m memiliki jumlah hasil tangkapan tertinggii yaitu 28106 ekor.Berdasarkan hasil uji-t untuk propabilitas (sig) sebesar 0,436>0,05, sehingga dapat diasumsikan bahwa perubahan variabel kedalaman (X2) tidak berpengaruh nyata terhadap hasil tangkapan ikan cakalang. 


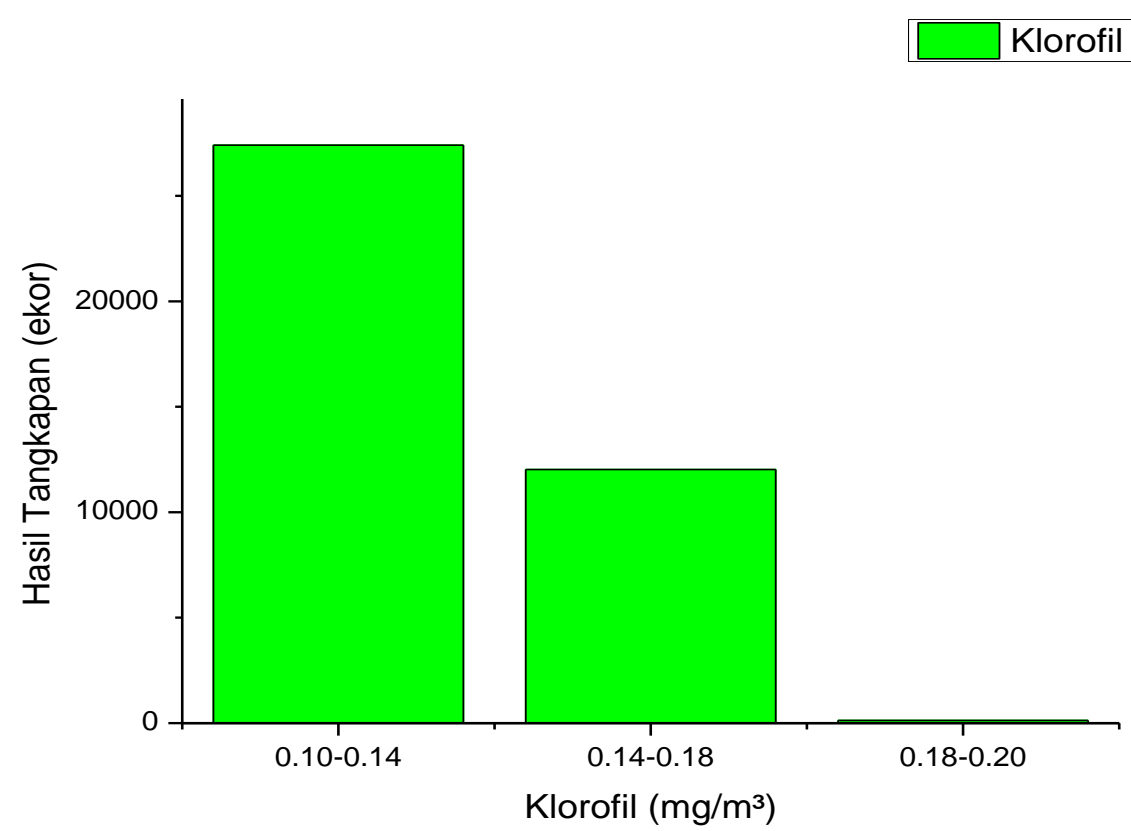

Gambar 4. Grafik hasil tangkapan ikan cakalang berdasarkan klorofil-a

uji-t untuk variabel klorofil-a (X3) diperoleh

Pada grafik di atas, dapat diketahui bahwa kandungan klorofil-a perairan antara 0,10-0,4 $\mathrm{mg} / \mathrm{m}^{3}$ memiliki jumlah hasil tangkapan tertinggi yaitu 30195 ekor.Berdasarkan hasil nilai propabilitas (sig) sebesar 0,049>0,05, sehingga dapat diasumsikan bahwa perubahan variabel klorofil-a (X3) berpengaruh nyata terhadap hasil tangkapan ikan cakalang.

Kec. Arus

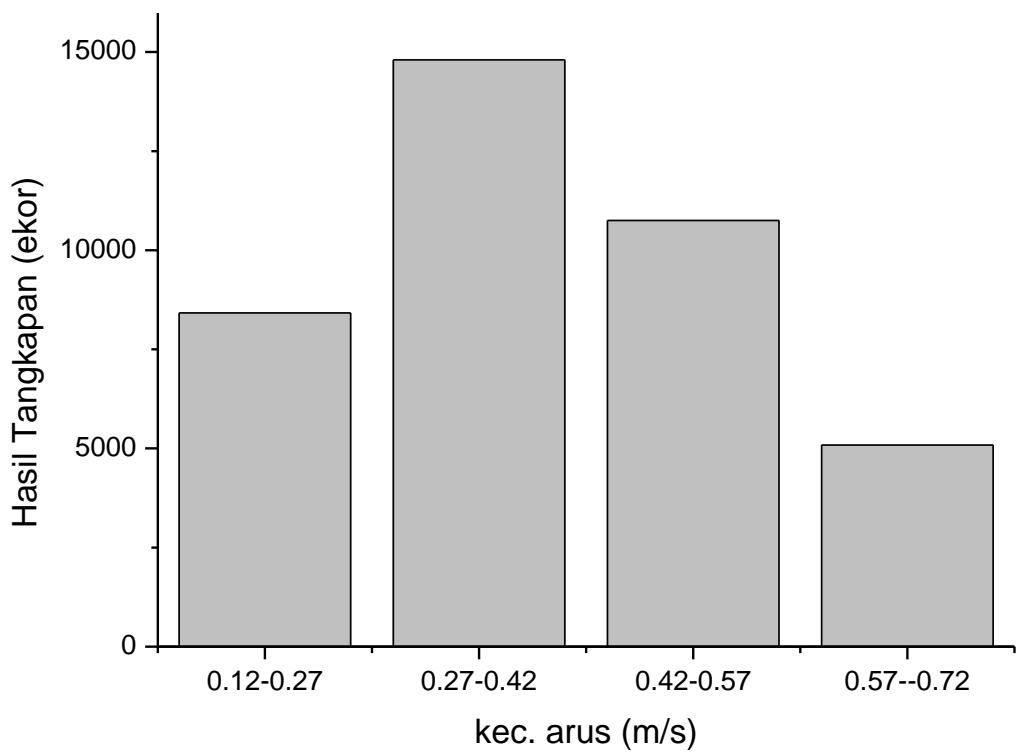

Gambar 5. Grafik hasil tangkapan ikan cakalang berdasarkan kec. Arus

Pada grafik di atas, dapat diketahui bahwa kecepatan arus antara 0,27-0,42 m/s memiliki 
jumlah hasil tangkapan tertinggii yaitu 15915 ekor. Berdasarkan hasil uji-t untuk variabel kec. arus (X4) diperoleh nilai propabilitas (sig) sebesar $0,008>0,05$, sehingga dapat

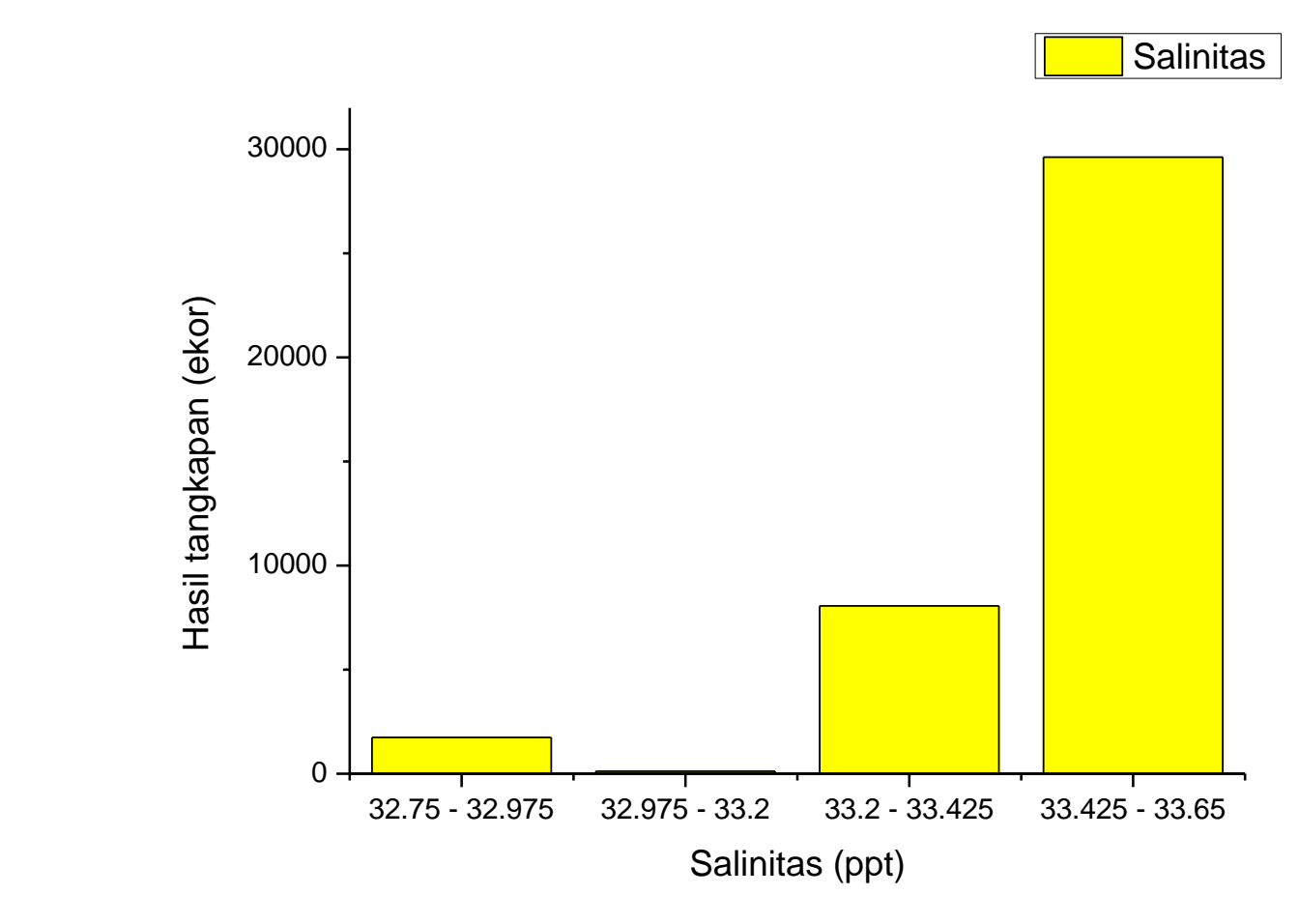

Gambar 6. Grafik hasil tangkapan ikan cakalang berdasarkan salinitas
Pada grafik di atas, dapat diketahui bahwa salinitas antara 33,42-33,65 ppt memiliki jumlah hasil tangkapan tertinggii yaitu 15915 ekor. Berdasarkan hasil uji-t untuk variabel salinitas (X5) diperoleh nilai propabilitas (sig) sebesar 0,011>0,05, sehingga dapat diasumsikan bahwa perubahan variabel salinitas (X5) berpengaruh nyata terhadap hasil tangkapan ikan cakalang. diasumsikan bahwa perubahan variabel kec. arus (X4) berpengaruh nyata terhadap hasil tangkapan ikan cakalang. 

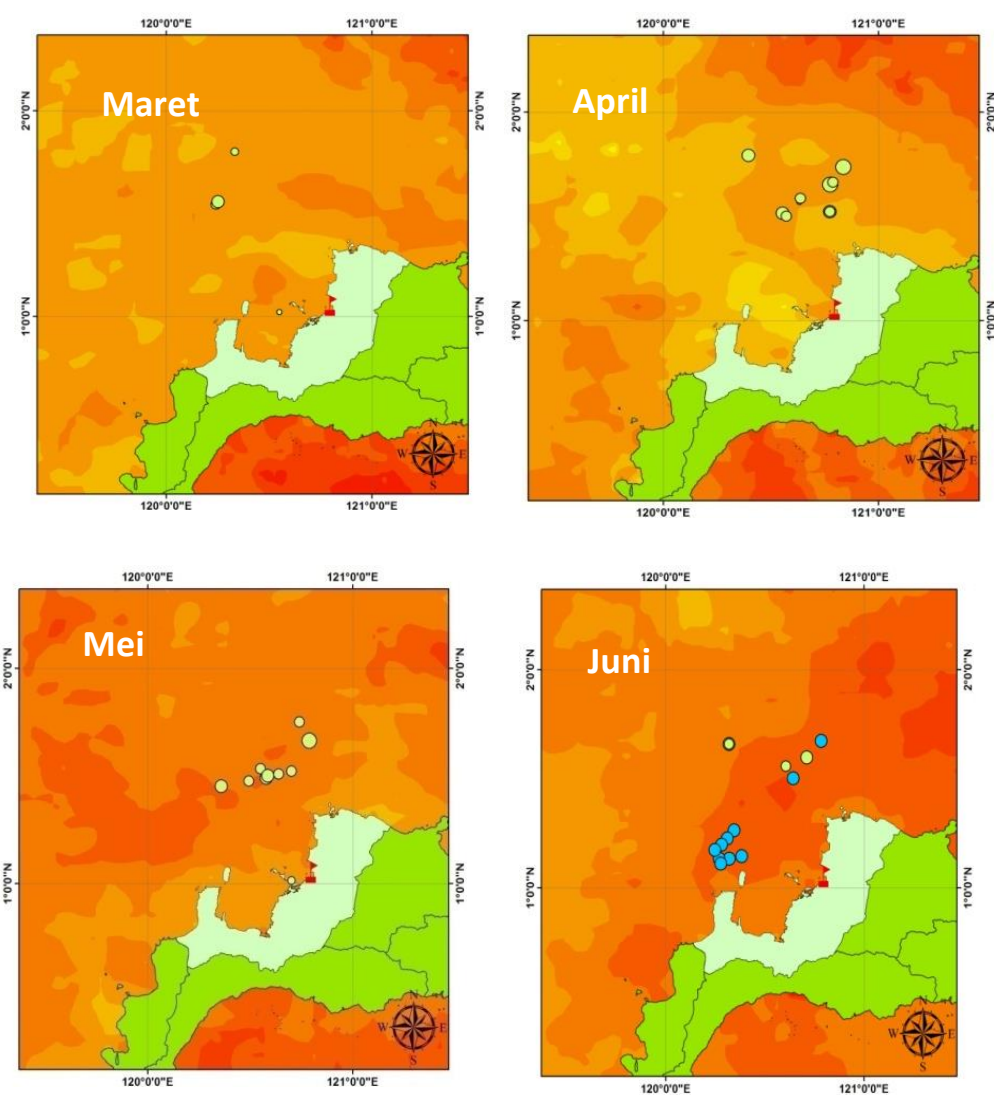

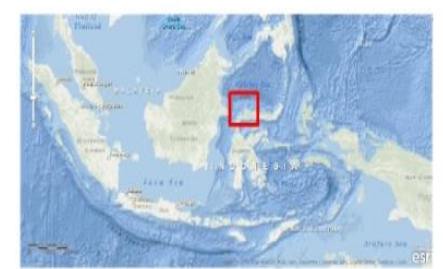

\section{Legend}

Fishing base Tangkapan (pole and line

$\square$ PULAU SULAWESI ${ }^{\circ} \quad 69-167$ KAB. TOLI-TOLI $\bigcirc \quad 168 \cdot 330$ SPL JUNI $2018^{\circ} \mathrm{C} \quad \mathrm{O} \quad 331.819$

\begin{tabular}{|c|c|c|}
\hline $28,14-28,68$ & 0 & $820 \cdot 1390$ \\
\hline $28,69 \cdot 29,22$ & 0 & $1391 \cdot 1689$ \\
\hline $29,23-29,77$ & Tangk & apan (purse se \\
\hline $29,78 \cdot 30,31$ & 0 & $69 \cdot 167$ \\
\hline 30,32 - 30,85 & 0 & $168 \cdot 330$ \\
\hline 30,86 - 31,39 & 0 & $331-819$ \\
\hline $31,4-31,94$ & & 820.1390 \\
\hline $31,95 \cdot 32,48$ & & 020.1290 \\
\hline 49.3302 & U & $1391 \cdot 1689$ \\
\hline
\end{tabular}

Sumber data : https.//oceancolor.gsfc nasa gov/ Datum World Geodetic system 1984 (WGS 84)

Gambar 7. Distribusi hasil tangkapan berdasarkan SPL Maret-Juni 2018 perairan Tolitoli
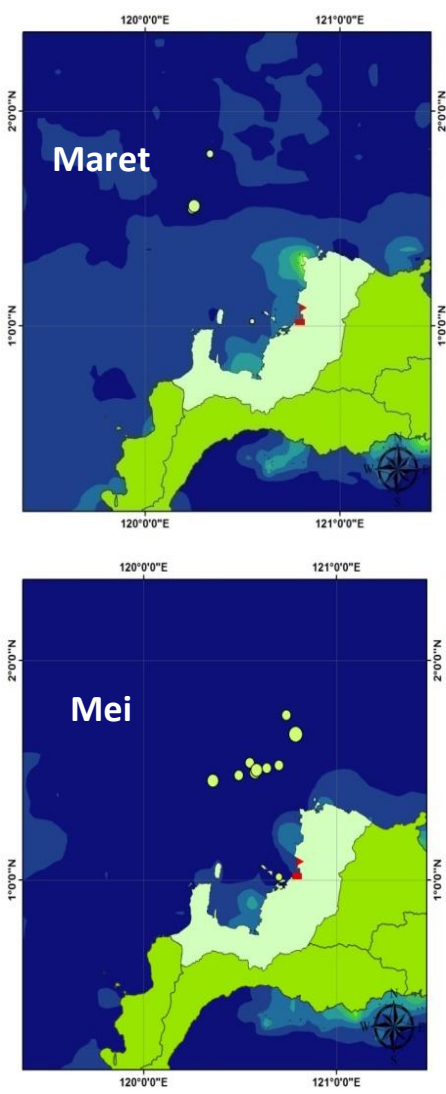
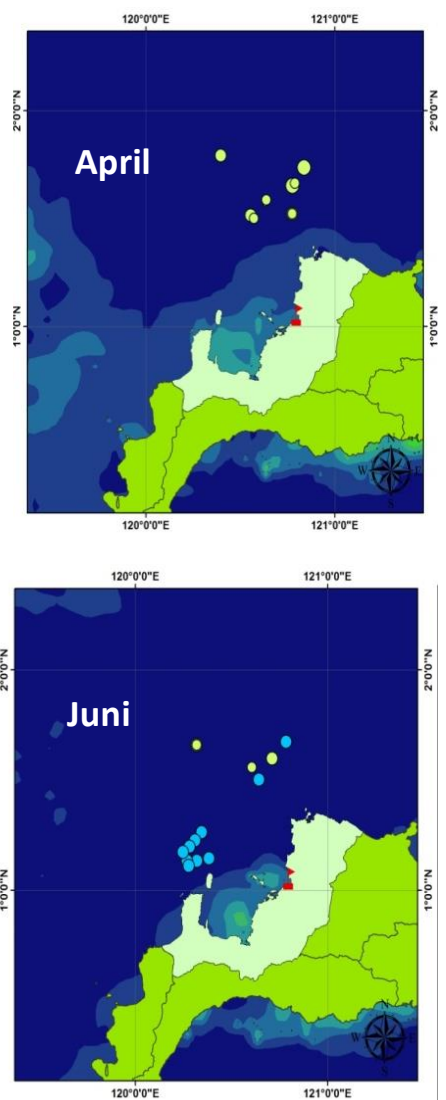

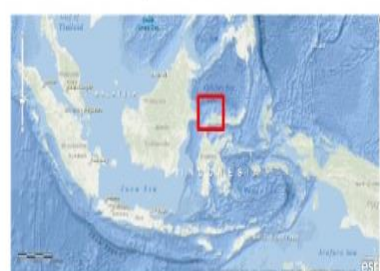

Legend

Fishing base Tangkapan (pole and line)

$\square$ PULAU SULANESI $\quad$ 69-167 $\square$ KAB. TOLLTOLI $0 \quad 168 \cdot 330$

Klorofilea (mg/m) $\quad$ O $\quad 331.819$

$\square, 0,07953 \cdot 0,1752 \quad 0 \quad 820 \cdot 1390$

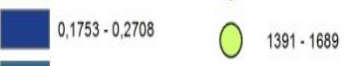

$0,2709 \cdot 0,3664$ Tangkapan (purse seine)

$0,3665 \cdot 0,4621 \quad 0 \quad 69 \cdot 167$

$0.4622-0,5577 \quad 0 \quad 168-330$

$\begin{array}{lll}0.5578 \cdot 0.6533 & \bigcirc & 331-819\end{array}$

$\square_{0,7491 \cdot 0,8446}^{0,6534 \cdot 0,749} \quad \mathrm{O}^{820 \cdot 1390}$

$\square 0.8447 \cdot 0.9403 \quad 1391-1889$

Sumber data : https.//oceancolor.gsfe nasa govl Datum World Geodetic system 1984 (WGS 84)

Gambar 8. Distribusi hasil tangkapan berdasarkan Klorofil-a Maret-Juni di Perairan Tolitoli 

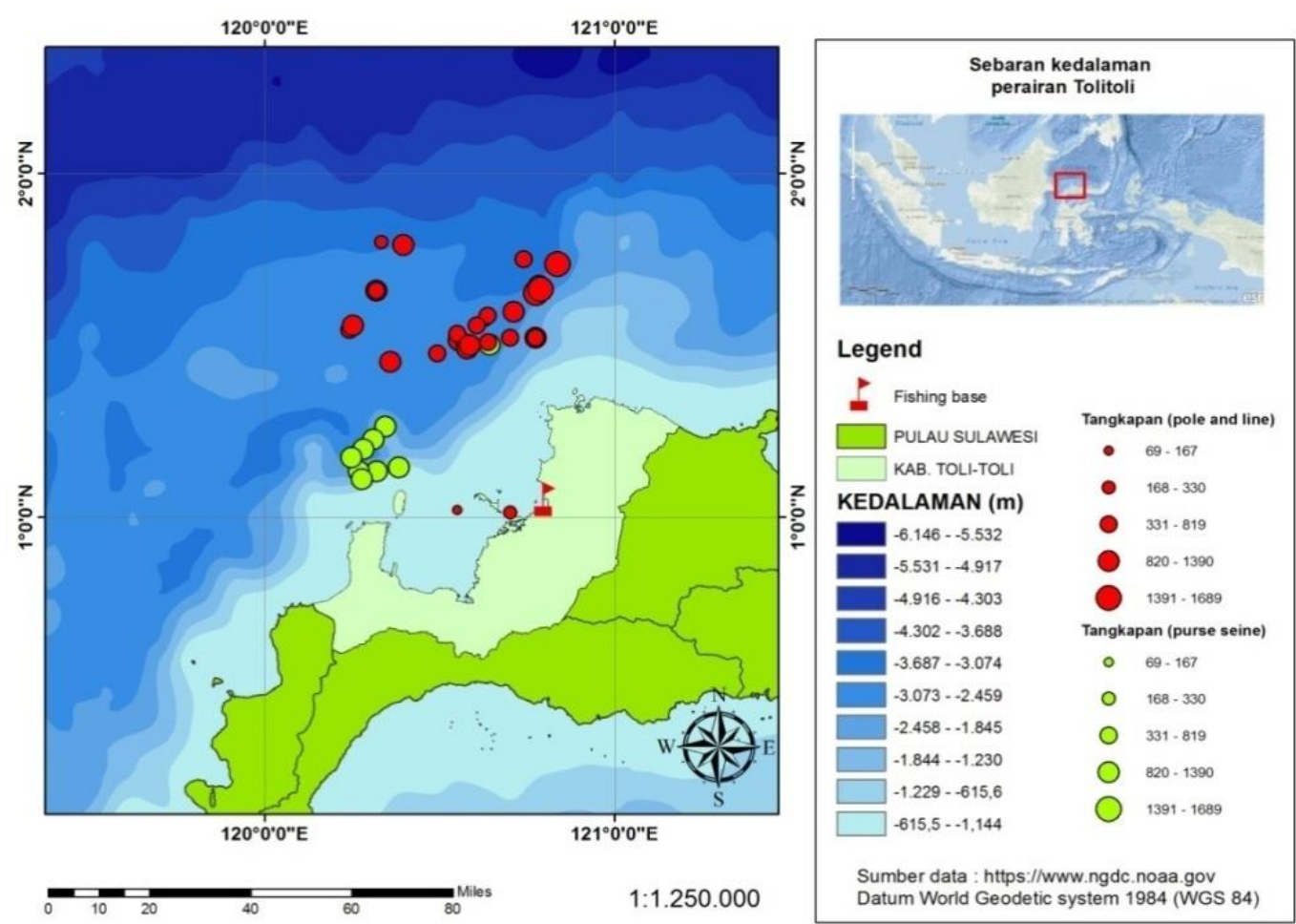

Gambar 11. Distribusi hasil tangkapan berdasarkan Kedalaman Perairan Tolitoli

Sebaran suhu permukaan laut di perairan Tolitoli pada bulan Maret-Juni 2018 (Gambar 7) berkisar antara $28,14-33,02{ }^{\circ} \mathrm{C}$. Distribusi penangkapan ikan cakalang pada suhu 29,5 $31,3{ }^{\circ} \mathrm{C}$. Tangkapan terbesar pada bulan April sebanyak 1689 ekor pada suhu $30,04{ }^{\circ} \mathrm{C}$, sedangkan tangkapan terendah sebanyak 69 ekor pada suhu $29,8{ }^{\circ} \mathrm{C}$. Sebaran titik penangkapan terdapat antara 120,2-120,8 BT dan 1,0-1,8 LU.

Sebaran klorofil-a di perairan Tolitoli pada bulan Maret-Juni 2018 (Gambar 8) berkisar antara $0,0795-0,9403 \mathrm{mg} / \mathrm{m}^{3}$. Distribusi penangkapan ikan cakalang pada pada kandungan klorofil-a $0,1048-0,2328 \mathrm{mg} / \mathrm{m}^{3}$. Tangkapan terbesar pada bulan April sebanyak 1689 ekor pada kandungan klorofil-a 0,1329 $\mathrm{mg} / \mathrm{m}^{3}$, sedangkan tangkapan terendah sebanyak 69 ekor pada kandungan klorofil-a $0,1524 \mathrm{mg} / \mathrm{m}^{3}$. Sebaran titik penangkapan terdapat antara 120,2-120,8 BT dan 1,0-1,8 LU.

Distribusi kecepatan arus di perairan Tolitoli pada bulan Maret-Juni 2018 berkisar antara $0,1084-0,8323 \mathrm{~m} / \mathrm{s}$. Distribusi penangkapan ikan cakalang pada kecepatan arus $0,1244-0,7232 \mathrm{~m} / \mathrm{s}$. Tangkapan terbesar pada bulan April sebanyak 1689 ekor pada kecepatan arus 0,2664 $\mathrm{m} / \mathrm{s}$, sedangkan tangkapan terendah sebanyak 69 ekor pada kecepatan arus $0,6255 \mathrm{~m} / \mathrm{s}$. Sebaran titik penangkapan terdapat antara 120,2-120,8 BT dan 1,0-1,8 LU.

Sebaran salinitas di perairan Tolitoli pada bulan Maret-Juni 2018 (Gambar 10) berkisar 
antara 32,39 - 34 ppt. Distribusi penangkapan ikan cakalang pada 32,74 - 33,64 ppt. Tangkapan terbesar pada bulan April sebanyak 1689 ekor pada tingkat salinitas perairan 33,52 ppt, sedangkan tangkapan terendah sebanyak 69 ekor pada tingkat salinitas 33,56 ppt. Sebaran titik penangkapan terdapat antara 120,2-120,8 BT dan 1,0-1,8 LU.

Kedalaman perairan di perairan Tolitoli diperoleh dari laman etopo-1 dengan resolusi $1 \mathrm{~km}$. Berdasarkan citra satelit kedalaman perairan Tolitoli berkisar 1,4 - $6146 \mathrm{~m}$ di bawah permukaan laut. Kedalaman renang tuna dan cakalang bervariasi tergantung dari jenisnya, umumnya tuna dan cakalang tertangkap di kedalaman 0 - $400 \mathrm{~m}$. Berdasarkan hasil pengambilan data, distribusi penangkapan ikan cakalang distribusi penangkapan ikan selama periode penelitian berada pada kedalaman 14 - 5513 m di bawah permukaan laut.

\section{Prediksi Daerah Penangkapan Potensial Ikan Cakalang (Katsuwonus pelamis)}

Zona optimum penangkapan ikan cakalang pada perairan Tolitoli diperoleh dari hasil overlay antara tiga data citra yakni klorofil-a, kecepatan arus, dan salinitas. Hasilnya akan terbentuk peta baru mengenai informasi prediksi daerah penangkapan ikan yang dikenal dengan zona penangkapan ikan cakalang.

Prediksi Daerah penangkapan potensial ikan cakalang pada bulan maret berada pada titik kordinat antara $1^{\circ} 14^{\prime} 40,767^{\prime \prime} L U$ sampai $2^{\circ} 22^{\prime} 32,697^{\prime \prime}$ LU dan antara 119³4'26,292"BT sampai $121^{\circ} 15^{\prime} 34,212^{\prime \prime B T}$ dengan total luas ZPPI tersebut $16.388,09 \mathrm{~km}^{2}$ dengan jumlah hasil tangkapan 125-922 ekor

Prediksi Daerah penangkapan potensial ikan cakalang pada bulan April berada pada titik kordinat antara $0^{\circ} 57^{\prime} 53,43 " \mathrm{LU}$ sampai $2^{\circ} 1$ '38,411"LU dan antara 119²4'58,034"BT sampai $121^{\circ} 16^{\prime} 19,228 " B T$ dengan total luas area ZPPI tersebut $13.309,62 \mathrm{~km}^{2}$ dengan jumlah hasil tangkapan 69-1689 ekor.

Prediksi Daerah penangkapan potensial ikan cakalang pada bulan Mei berada pada titik kordinat antara $0^{\circ} 58$ '24,176" LU sampai $2^{\circ} 22^{\prime} 53,22^{\prime \prime}$ LU dan antara 1204'5,133" BT sampai $121^{\circ} 16^{\prime} 4,157^{\prime \prime} B T$ dengan total luas area ZPPI tersebut $15.170,79 \mathrm{~km}^{2}$ dengan jumlah hasil tangkapan 190-1460 ekor.

Prediksi Daerah penangkapan potensial ikan cakalang pada bulan Juni berada pada titik kordinat antara $0^{\circ} 53^{\prime} 1,542 " L U$ sampai $2^{\circ} 22^{\prime} 54,905^{\prime \prime L U}$ dan antara 119³2'33,626" BT sampai $121^{\circ} 15^{\prime} 57,09^{\prime \prime}$ BT dengan total luas ZPPI tersebut $16.461,75 \mathrm{~km}^{2}$. dengan jumlah hasil tangkapan 480-1389 ekor. 


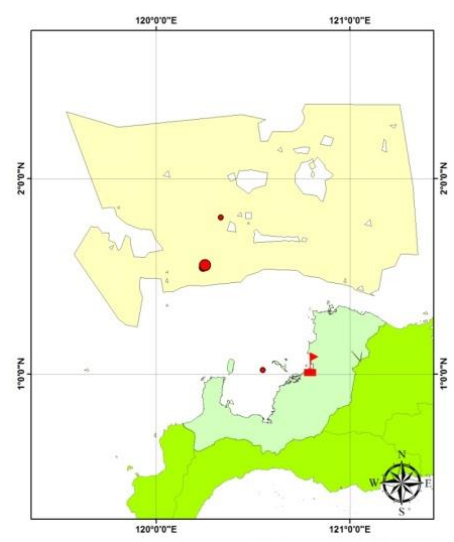

Maret

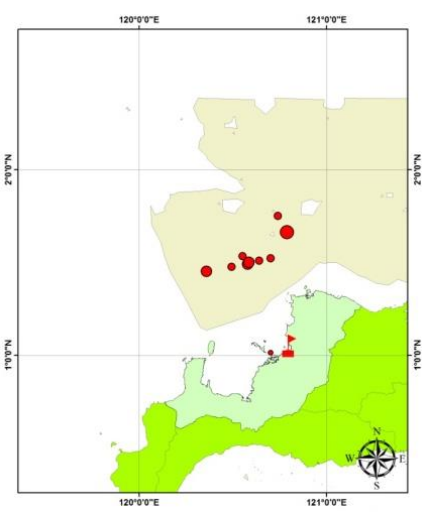

Mei

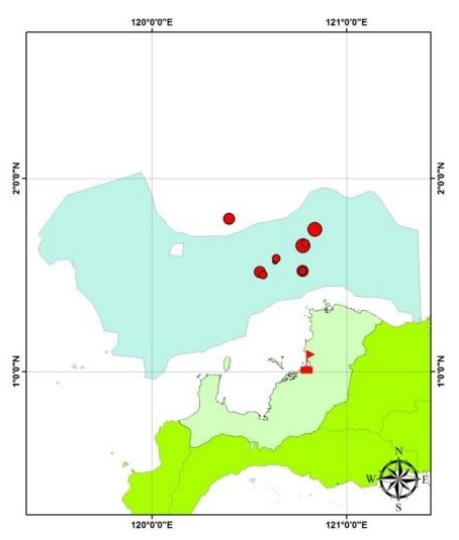

April

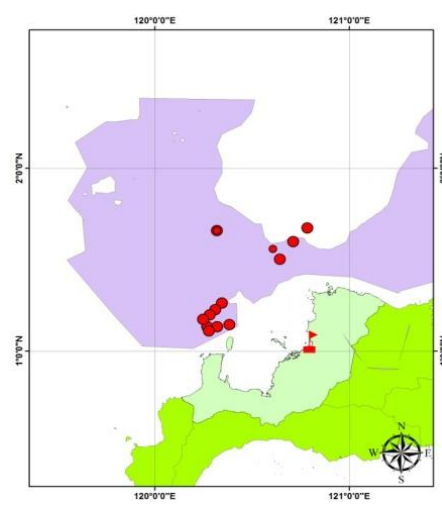

Juni

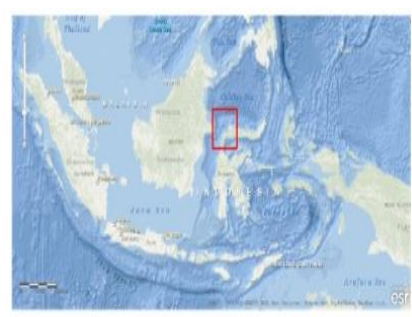

Legend

FISHING BASE

SULAWES

TOLI-TOLI
Hasil tangkapan (ekor)

- $69-330$

- $\quad 331-819$

- $820-1390$

$1391-1689$

Gambar 12. Prediksi daerah potensial ikan cakalang Maret-Juni di perairan Tolitoli

\section{KESIMPULAN}

Berdasarkan tujuan penelitian yang dilakukan maka dapat ditarik beberapa kesimpulan yakni

1. Parameter oseanografi yang memiliki hubungan nyata terhadap hasil tangkapan ikan cakalang selama periode penelitian adalah klorofil-a, kecepatan arus dan salinitas.

2. Distribusi Daerah penangkapan ikan cakalang di perairan kabupaten Tolitoli selama periode penelitian sebaran titik penangkapan terdapat antara 120,3-120,8 BT dan 1,0-1,7 LU. Dengan kisaran suhu permukaan laut $29,5-31,1^{\circ} \mathrm{C}$, kedalaman 14,20 - 5513 mdpl, konsentrasi klorofil-a $0,10-0,23 \mathrm{mg} / \mathrm{m}^{3}$, kecepatan arus 0,12$0,72 \mathrm{~m} / \mathrm{s}$ dan salinitas $32,74-33,64 \mathrm{ppt}$.

3. Prediksi daerah potensial penangakapan ikan cakalang secara spasial dan temporal selama periode penelitian di kabupaten Tolitoli umumnya berada perbatasan antara selat makassar dan laut sulawesi. Berada antara titik kordinat $0^{\circ} 57^{\prime} 53,43^{\prime \prime} \mathrm{LU}$ sampai 
$2^{\circ} 1$ '38,411"LU dan antara $119^{\circ} 24^{\prime} 58,034$ "BT sampai $121^{\circ} 16^{\prime} 4,157^{\prime \prime} B T$ dengan total luas area ZPPI $16.461,75 \mathrm{~km}^{2}$.

\section{DAFTAR PUSTAKA}

Dinas Kelautan dan Perikanan kabupaten Tolitoli. 2018. Laporan Statistik Perikanan Kabupaten Tolitoli. Dinas Perikanan dan Kelautan Kabupaten Tolitoli.

Ramadhani. Y, 2011. Analisis Efisiensi ,Skala dan Elastisitas Produksi Dengan Pendekatan Cobb Douglas dan Regresi Berganda. Jurnal Teknologi Vol. 4 (1), Juni 2011 : 53-61.

Sadhori, N. 1985. Teknik Penangkapan Ikan. Bandung: Angkasa.

Watimury, J. J., 1998. Penentuan Zona Konsentrasi Ikan Cakalang dan Madidihang (yellowfin tuna) di Perairan Ambon dan Sekitarnya Menggunakan Data NOAA/ AVHRR dan Sistem Informasi Geografis. Skripsi. Program Studi Penginderaan Jauh Jurusan Ilmu-Ilmu Matematika dan Ilmu Pengetahuan Alam. UGM Yogyakarta.

Wirasatriya, A. 2011. Pola Distribusi Klorofil-a dan Total Suspended Solid (TSS) di Teluk Toli Toli, Sulawesi. Buletin Oseanografi Marina Oktobe 2011.vol.1137- 149.

Yuliani, Eddy Mantjoro, Adnan Wantasen, dan Markus T. Lasut. Kajian potensii pengembangan sumberdaya perikanan di wilayah pesisir Kabupaten Tolitoli. Aquatic Science \& Management, Edisi Khusus 1, 17-25 (Mei 2013).

Zainuddin, M. 2006. Aplikasi Sistem Informasi Geografis Dalam Penelitian Perikanan Dan Kelautan. Disampaikan Pada
Lokakarya Agenda Penelitian COREMAP II Kebupaten Selayar. Selayar. 